\title{
Sklanjatev in naglas samostalnikov moške $o$-jevske sklanjatve v govoru vasi Jevšček pri Livku nadiškega narečja slovenščine
}

\author{
Matej Šekli
}

V članku sta obravnavana sklanjatev in naglas samostalnikov moške $o$-jevske sklanjatve v krajevnem govoru vasi Jevšček pri Livku (občina Kobarid, Slovenija) nadiškega narečja slovenščine, in sicer tako s sinhronega kot z diahronega gledišča. Opisnojezikoslovni vidik podaja nabor končnic in njihovo razvrstitev na osnovo ter naglasne tipe in njihove naglasne vzorce. Zgodovinskojezikoslovni pogled določa izvor posameznih končnic in naglasnih tipov ter opisani oblikovno-naglasni sistem postavlja v širši slovenski in slovanski kontekst.

Ključne besede: nadiško narečje slovenščine, zgodovinsko jezikoslovje, narečjeslovje, (obliko)naglasoslovje, samostalniki moške $o$-jevske sklanjatve, Jevšček pri Livku

\section{Declension and accentuation of masculine $o$-stem nouns in the local dialect of Jevšček near Livek in the Natisone/Nadiža dialect of Slovenian}

This paper discusses the declension and accentuation of masculine $o$-stem nouns in the local subdialect of Jevšček (in the Municipality of Kobarid, Slovenia) of the Natisone/Nadiža dialect of Slovenian from the diachronic and the synchronic points of view. The descriptive linguistic perspective presents the inventory of endings and their stem distribution as well as the accent classes and their paradigms. The historical linguistic part determines the origin of these endings and accent classes and contextualizes the morphological and accentual system described within Slovenian and other Slavic languages.

Key words: Natisone/Nadiža dialect of Slovenian, historical linguistics, dialectology, (morpho)accentology, masculine $o$-stem nouns, Jevšček near Livek

\section{Uvod}

$\mathrm{V}$ pričujočem članku ${ }^{1}$ sta obravnavana sklanjatev in naglas samostalnikov moške $o$-jevske sklanjatve ${ }^{2}$ v govoru vasi Jevšček pri Livku (občina Kobarid, Slovenija)

1 Vsebina prispevka je bila predstavljena v obliki referata na mednarodnem simpoziju Slovenski dialekti v stiku 4 (Koper, 28.-30. maj 2009)

2 Moška $o$-jevska sklanjatev je tu razumljena sinhrono. Vanjo tako spadajo vsi samostalniki, ki se v opisanem govoru sklanjano po sklanjatvenem vzorcu, ki ima za osnovo sklanjatveni vzorec popraslovansko produktivne praslovanske moške $o$-jevske sklanjatve ter je vase vsrkal tudi nekatere oblike praslovanske $u$-jevske in praslovanske (moške) $i$-jevske sklanjatve, v nekaterih oblikah pa se je po naliki približal tudi sklanjatvenemu vzorcu praslovanske $\bar{a}$-jevske sklanjatve. Posledično sem spadajo tudi samostalniki, ki so se 
nadiškega narečja slovenščine, ${ }^{3}$ in sicer tako s sinhronega kot $\mathrm{z}$ diahronega gledišča. Opisnojezikoslovni vidik prinaša strukturalni opis oblikovno-naglasnega sistema, to je nabor/inventar njegovih prvin in njihovo razvrstitev/distribucijo ter vlogo/ funkcijo in medsebojno razmerje $\mathrm{v}$ sistemu, $\mathrm{v}$ konkretnem primeru nabor končnic in njihovo razvrstitev na osnovo ter naglasne tipe in njihove naglasne vzorce. Zgodovinskojezikoslovni pogled posamezni prvini opisanega sistema, v konkretnem primeru posameznim končnicam in naglasnim tipom, določa njen praslovanski in izhodiščni splošnoslovenski izvor. Praslovansko izhodišče je določeno na osnovi spoznanj (zgodovinskega) primerjalnega naglasoslovja slovanskih jezikov druge polovice 20. stoletja, in sicer njegovega osrednjega in standardnega, tj. »oblikoslovnega« metodološkega pristopa (ob upoštevanju »glasoslovnega«), ki se pojavlja v delu Christiana S. Stanga Slavonic Accentuation (Stang 1957) in v iz njega izhajajočih delih avtorjev moskovske naglasoslovne šole od prvih naglasoslovnih objav Vladimira Antonoviča Dyboja od leta 1958 dalje. ${ }^{4}$ Izhodiščno splošnoslovensko stanje je izpeljano iz praslovanskega ob upoštevanju dejanskega izpričanega stanja $\mathrm{v}$ slovenskih krajevnih govorih in spoznanj slovenističnega zgodovinskega naglasoslovja, v prvi vrsti članka Frana Ramovša »Relativna kronologija slovenskih akcentskih pojavov« in naglasoslovne razprave Jakoba Riglerja. ${ }^{5}$ Tak diahroni komentar $\mathrm{k}$ sinhronemu delu razprave omogoča, da obravnavane prvine jezikovnega sistema opisanega krajevnega govora postanejo genetskojezikoslovno primerljive s prvinami drugih jezikovnih sistemov $\mathrm{v}$ okviru slovenščine in drugih slovanskih jezikov.

\section{Sklanjatev}

\subsection{Nabor koněnic: ${ }^{6}$}

\begin{tabular}{|c|c|c|c|c|c|}
\hline$-\varnothing$ & $-a /-u$ & $-u$ & $=\mathrm{im} . / \mathrm{rod}$ & $-e$ & $-a n$ \\
\hline$-\varnothing /-i /-i \cdot e$ & $-u /-\grave{o}: u /-l^{\prime} x^{\prime}$ & $-a n /-\grave{e}: n$ & $-e /-i_{i}$ & -ax/-íex & $-m i$ \\
\hline$-a$ & $=\mathrm{mn}$ & $=\mathrm{mn}$ & $-a$ & $=\mathrm{mn}$ & $=\mathrm{mn}$. \\
\hline
\end{tabular}

Končnice so nenaglašene ali naglašene; naglašene končnice so kratke ali dolge, dolge pa cirkumflektirane ali akutirane.

prvotno sklanjali po praslovanski $u$-jevski in praslovanski (moški) $i$-jevski sklanjatvi ter so popraslovansko prešli v moško $o$-jevsko sklanjatev: Jevšček tà̀t tatùr, sìnn sì:na $\leftarrow$ psl. *tatb *tati, *synъ *synu.

3 Informator na terenu je bil Leopold Šekli (roj. 1939). Za nepogrešljivo pomoč se mu najlepše zahvaljujem.

4 Stang 1957; Dybo 1981, 2000; Dybo - Zamjatina - Nikolajev 1990, 1993.

5 Ramovš 1950; Rigler 1970, 1971, 1977, 1978.

Spoznanja (zgodovinskega) primerjalnega naglasoslovja slovanskih jezikov druge polovice 20. stoletja in slovenističnega zgodovinskega naglasoslovja so povzeta in na konkretni naglasni sistem aplicirana v Šekli 2008.

${ }^{6} \mathrm{~V}$ preglednicah si v stolpcih navpično sledijo skloni (imenovalnik, rodilnik, dajalnik, tožilnik, mestnik, orodnik), v vrsticah vodoravno števila (ednina, množina, dvojina). 
(a) Nenaglašene končnice:

\begin{tabular}{|llllll|}
\hline$-\varnothing$ & $-a$ & $-u$ & $=\mathrm{im} . / \mathrm{rod}$. & $-e$ & $-a n$ \\
$-\varnothing /-i$ & $-u$ & $-a n$ & $-e$ & $-a x$ & $-m i$ \\
$-a$ & $=\mathrm{mn}$. & $=\mathrm{mn}$. & $-a$ & $=\mathrm{mn}$. & $=\mathrm{mn}$. \\
\hline
\end{tabular}

(b) Kratke naglašene končnice:

\begin{tabular}{|c|c|c|c|c|c|}
\hline I & '- $a$ & '-u & $\mathrm{im} . / \mathrm{rod}$. & '-e & '-an \\
\hline${ }^{\prime}-i$ & / & '-an & $'-e$ & $'-a x$ & / \\
\hline '- $a$ & $=\mathrm{mn}$. & $=\mathrm{mn}$. & '- $a$ & $=\mathrm{mn}$. & $=\mathrm{mn}$. \\
\hline
\end{tabular}

(c) Dolge naglašene končnice:

\begin{tabular}{|c|c|c|c|c|c|}
\hline / & $-\grave{a} \cdot /-\grave{u}_{i}$ & $-\grave{u}:$ & im./rod. & I & I \\
\hline -ì:e & $-\grave{o} \cdot u /-i^{\prime}$ & $-\grave{e}: n$ & $-\grave{e}: / \grave{l}_{:}$ & -íex & $-m i^{\prime}$ \\
\hline$-\grave{a}:$ & $=\mathrm{mn}$. & $=\mathrm{mn}$. & $-\grave{a}:$ & $=\mathrm{mn}$. & $=\mathrm{mn}$. \\
\hline
\end{tabular}

1.2 Razvrstitev končnic na osnovo je sinhrono gledano določena predvsem z naglasnim tipom samostalnika kot tudi s podspolom neživo : živo (genus inanimatum : genus animatum). Naglasni tip samostalnika je pomemben pri razvrstitvi končnic $\mathrm{v}$ im. mn., rod. mn., daj. mn., mest. mn. V rod. mn. se končnica $\boldsymbol{- u}$ pojavlja pri samostalnikih $\mathrm{z}$ nepremičnim in premičnim naglasnim tipom (brà:tu, klùùcu, kùrosu, sosìredu), končnica -ò̀u pri samostalnikih s končniškim naglasnim tipom (końò $u$ ), končnica $\boldsymbol{t}_{\boldsymbol{i}}$ : pri samostalnikih z mešanim naglasnim tipom (moží, zidí). V im. mn., daj. mn., mest. mn. sta dvojnični končnici dopolnjujoče razvrščeni, ena dvojnica se pojavlja pri samostalnikih z nepremičnim in premičnim naglasnim tipom in končniškim naglasnim tipom, druga pa pri samostalnikih z mešanim naglasnim tipom: im. mn. -i/'-i : -ì̀e (brá:ti, kíúuči, kùrosi, sosíredi, ko'ńi : možì̀e, zidì̀e), daj. mn. -an/'-an : -è̀n (brá:tan, klúučan, kùrosan, sosíedan, ko'ńan : možè:n, zidè:n), mest. mn. -ax/'-ax : -írex (brá:tax, kĺúučax, kù:osax, sosíredax, ko'ńax : možíex, zidíex). V im. mn. se pri samostalnikih z osnovo ne na soglasniški sklop (ne)zvočnik + zvočnik ob končnici -i/'-i redkeje pojavlja tudi končnicica - (sanosí:ek, ot'roc). Podspol neživo : živo je poleg naglasnega tipa relevanten pri razvrščanju končnice rod. ed. in tož. mn. V rod. ed. je končnica -ùu: značilna samo za samostalnike $\mathrm{z}$ mešanim naglasnim tipom in $\mathrm{s}$ podspolom neživo (zidù:) (edini samostalnik s podspolom živo je tà:t (tatùi)), in je pri le-teh daleč najpogostejša, končnica -àr je edina končnica samostalnikov z mešanim naglasnim tipom in s podspolom živo (možàr, ukà:), zelo redko jo imajo tudi samostalniki z mešanim naglasnim tipom in s podspolom neživo. $V$ tož. mn. je končnica -èr značilna za samostalnike z mešanim naglasnim tipom in s podspolom živo (možèè, ukè:) in za redke samostalnike s podspolom neživo (lasèr, pasèr, royèr, uozè:, zobèr, zuonè:), končnica -ì̀ pa za samostalnike s podspolom neživo (zidì); edini samostalnik s podspolom živo je tàıt (tatì). 
1.3 Izvor koněnic: ${ }^{7}$ im. ed. $-\boldsymbol{\sigma}<$ issln. ${ }_{-}-\varnothing<$ psl. ${ }_{-}-b /{ }_{-b}$; rod. ed. $\boldsymbol{a}<<$ issln.

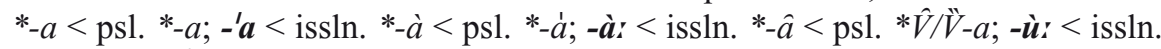
$*_{-} \hat{u}<$ psl. $* \hat{V} / \vec{V}-u$; daj. ed. $-\boldsymbol{u}<$ issln. ${ }^{*}-u<$ psl. ${ }^{*}-u ;-{ }^{-} \boldsymbol{u}<$ issln. ${ }^{*} \grave{u}<$ psl. ${ }^{*}-\dot{u} ;-\grave{u} z$

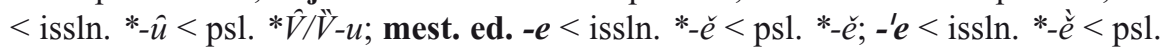

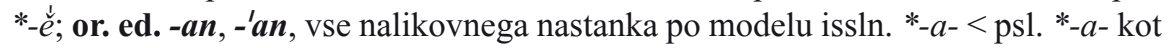
(s praslovanskega stališča) prvega dela kočnice daj., mest. in or. mn. samostalnikov $\bar{a}$-jevske sklanjatve (issln. ${ }^{*}-a-m,{ }^{*}-a-x,{ }^{*}-a-m i$ ter daj. or. dv. ${ }^{*} a-m a<$ psl. ${ }^{*}-a-m b$, $*_{-} a-x b, *_{-} a-m i$ ter daj. or. dv. ${ }_{-}^{*} a-m a$ ) in issln. ${ }_{-} m<$ psl. ${ }_{-}-m b$ kot (s praslovanskega stališča) drugega dela končnice or. ed. samostalnikov moške in srednje $o$-jevske sklanjatve (issln. ${ }_{-o-}-m / *_{-}-e-m<$ psl. $\left.*_{-o-m b} / *_{-} e-m b\right)$; im. mn. $-\boldsymbol{o} /-\boldsymbol{i}<$ issln. $*_{-} i$

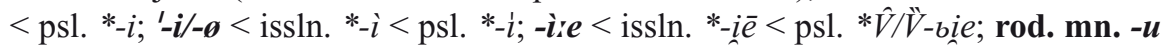
$<$ issln. *ou< psl. *-ouъ; -òr $u \leq$ issln. *-óu < psl. *-òuъ po nalikovni nadomestitvi akuta na dolžini s cirkumfleksom na dolžini po zgledu samostalnikov z naglasom na osnovi v rod. mn.; $-\boldsymbol{i}_{i}^{\prime}<$ issln. ${ }^{*}{ }_{-} i<$ psl. ${ }^{*}$-bib; daj. mn. -an, preneseno iz oblike daj. mn. samostalnikov $\bar{a}$-jevske sklanjatve (-an < issln. *-am < psl. *-amb); -è̀n

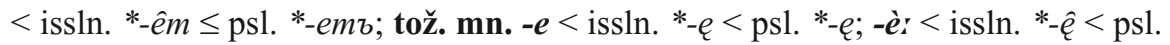
$* \hat{V} / \vec{V}-e ;-\boldsymbol{i}_{i}<$ issln. ${ }^{*} \hat{\imath}<$ psl. $* \hat{V} / \vec{V}-i$; mest. mn. $-\boldsymbol{a x}$, preneseno iz oblike mest. mn. samostalnikov $\bar{a}$-jevske sklanjatve (-ax $<$ issln. *-ax $<$ psl. *-axъ); -í' $e x<$ issln. *-éx

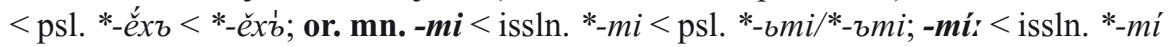
$<$ psl. ${ }^{*}$-bmi/*-bmi; im./tož. dv. $-\boldsymbol{a}<$ issln. ${ }^{*}-a<$ psl. ${ }_{-}-a$; ${ }^{\prime}-\boldsymbol{a}<$ issln. ${ }_{-}^{*} a \dot{a}<$ psl. ${ }_{-}^{*} \dot{a}$; $-\grave{a}:<$ issln. $*-\hat{a}<$ psl. $* \hat{V} / \vec{V}-a$.

Končnice samostalnikov moške $o$-jevske sklanjatve v obravnavanem govoru diahrono gledano le $\mathrm{v}$ glavnih obrisih nadaljujejo končnice praslovanske moške $o$-jevske sklanjatve, saj so bile prvotne končnice ponekod nadomeščene s končnicami praslovanske $u$-jevske in (moške) $i$-jevske sklanjatve ter preoblikovane pod vplivom $\bar{a}$-jevske sklanjatve. Razlikovanje med odrazi praslovanske trde in praslovanske mehke moške $o$-jevske sklanjatve ni ohranjeno: 1 . trda končnica se je posplošila v mest. ed. (-e, '-e<psl. *-ě), mest. mn. samostalnikov z mešanim naglasnim tipom (-íex < psl. *-ěxz); 2. mehki končnici sta se posplošili v tož. mn. (-e, $'-e,-\grave{e}:<$ psl. *ee), daj. mn. samostalnikov z mešanim naglasnim tipom $(-\grave{e}: m<$ psl. *-emъ); 3. prvotno končnico je mogoče izvajati tako iz trde kot iz mehke sklanjatve v im. ed. $\left(-\varnothing<\right.$ psl. $\left.{ }_{-}^{*}-{ }^{*}{ }_{-} b\right)$, rod. ed. (dvojnično $-a,{ }^{\prime}-a,-\grave{a}_{:}<$psl. $\left.{ }^{*}-a\right)$, daj. ed. $(-u$, $'-u,-\grave{u}_{:}<$psl. $\left.{ }^{*}-u\right)$, im. mn. $\left(-\varnothing /-i,{ }^{\prime}-i,-\grave{l}^{\prime}<\right.$ psl. $\left.{ }^{*}-i\right)$. Končnice praslovanske $u$-jevske sklanjatve se pojavljajo v rod. ed. samostalnikov z mešanim naglasnim tipom (dvojnično $-\grave{u}:<$ psl. $\left.{ }^{*}-u\right)$, rod. mn. samostalnikov s končniškim naglasnim tipom (-ò’u $<$ psl. *-oű). Končnice praslovanske (moške) $i$-jevske sklanjatve so prevladale v im. mn. samostalnikov z mešanim naglasnim tipom (-ìe < psl. *-bie), rod. mn. samostalnikov z mešanim naglasnim tipom ( $-i^{\prime}<$ psl. *-bịb), tož. mn. samostalnikov

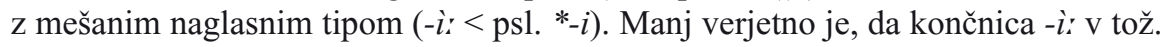
mn. nadaljuje praslovansko končnico trde moške $o$-jevske sklanjatve *-y. Končnico or. mn. je mogoče izvajati tako iz psl. $i$-jevske kot $u$-jevske sklanjatve $(-m i,-m i$ : $<$ psl. ${ }_{-}^{*}$-bmi/*-bmi). Končnici praslovanske $\bar{a}$-jevske sklanjatve sta prodrli v daj. $\mathrm{mn}$. in mest. mn. samostalnikov z nepremičnim, premičnim in končniškim nagla- 
snim tipom (-an, '-an < psl. *-amb in -ax, '-ax< psl. *-axb), na osnovi le-teh pa je bila narejena še končnica or. ed. (-an, '-an < psl. *-a- + *-mb).

Nekateri (iz stičnih jezikov ali iz slovenskega knjižnega jezika prevzeti) samostalniki v im. ed. poznajo nenaglašeno kočnico -o (à:uto, mè:štro star. 'učitelj med obema vojnama pod Italijo', nò:no 'dedek', trè:no star. 'vlak'), v ostalih sklonih pa se sklanjajo po sklanjatvenem vzorcu moške $o$-jevske sklanjatve. Nekateri (iz nemščine ali iz slovenskega knjižnega jezika prevzeti) samostalniki z osnovo na -l- le-to v odvisnih sklonih podaljšujejo z -n- (krá:ncul krá:nculna 'venec', štá:mpel štá:mpelna 'kozarček žganja', učìtel učìtelna 'učitelj'). Redki samostalniki se ne sklanjajo z glasovno izraženo končnico (podešta v rabi do leta 1943 ‘župan’).

\section{$2 \quad \operatorname{Naglas}^{8}$}

Naglasni tipi samostalnikov moške $o$-jevske sklanjatve so s sinhronega stališča določeni na osnovi naglasa im. ed. in rod. ed. ter so tile: 1. nepremični naglasni tip z akutom na osnovi: (a) tip s kolikostno premeno in brez neobstojnega samoglasnika v im. ed.: tip b'rat brá:ta, člo'vek človíreka; (b) tip brez kolikostne premene in brez neobstojnega samoglasnika v im. ed.: tip klú:č klúuča, roká:u rokárva, já:uor já:uorja; (c) tip brez kolikostne premene in z neobstojnim samoglasnikom v im. ed.: tip rá:bər yá:bra, ká:men ká:mna; 2. nepremični naglasni tip s cirkumfleksom na osnovi: tip xlìepc xlì'epca; 3. premični naglasni tip (z akutom na osnovi): tip só:set sosíreda; 4. končniški naglasni tip: tip 'koń ko'ńa; 5. mešani naglasni tip: tip zìt zidù.'

\subsection{Tip 'kup kú:pa, b'rat brá:ta}

Samostalniki naglasnega tipa 'kup kú:pa, b'rat brá:ta imajo nepremični naglasni tip $z$ akutom na osnovi, in sicer $z$ naglasnim mestom na edinem/zadnjem zlogu osnove s kolikostno premeno in brez neobstojnega samoglasnika v im. ed. ('kup kú:pa, člo'vek človíreka). V večini sklonskih oblik poznajo akut na dolžini, v im. ed. kračino, v rod. mn. in or. mn. pa cirkumfleks na dolžini.

(a) Samostalniki s podspolom neživo

\begin{tabular}{|llllll|}
\hline 'kup & kú:pa & kú:pu & 'kup & kú:pe & kú:pan \\
kú:pi & kù:pu & kú:pan & kú:pe & kú:pax & kù:pmi \\
kú:pa & $=\mathrm{mn}$. & $=\mathrm{mn}$. & kú:pa & $=\mathrm{mn}$. & $=\mathrm{mn}$. \\
\hline
\end{tabular}

(b) Samostalniki s podspolom živo

\begin{tabular}{|llllll|}
\hline b'rat & brá:ta & brá:tu & brá:ta & brá:te & brá:tan \\
brá:ti & brà:tu & brá:tan & brá:te & brá:tax & brà:tmi \\
brá:ta & $=\mathrm{mn}$. & $=\mathrm{mn}$. & brá:ta & $=\mathrm{mn}$. & $=\mathrm{mn}$. \\
\hline
\end{tabular}

8 Tonemski naglas samostalnikov moške $o$-jevske sklanjatve v (knjižni) slovenščini je bil natančneje obdelan v Valjavec 1878; Škrabec 1895: 233-234, 236-238, 244-246; Rigler v SSKJ 1: § 191, 205; Toporišič 2000: 284-288; SP 2001: § 901-913, 1187, 1191, 1196. 
Izvor:

< psl. *küpr *küpa, *iezÿkr *iezÿka (a) (> issln. *kùp *kùpa, *ięzik *ięzika $>$ nad. 'kup kú:pa, i'zik izí:ka, knj. sln. küp kúpa, jézik jezika), in sicer samostalnikov z naglasom na edinem/zadnjem zlogu osnove, pri čemer je prišlo do naslednjih (naglasnih in nalikovnih) sprememb: 1. zgodnje podaljšanje issln. kratkih akutiranih zložnikov v nezadnjem besednem zlogu v zahodnih in južnih slovenskih narečjih; 2. nalikovna izravnava issln. cirkumfleksa na dolžini $z$ akutom na dolžini v mest. mn. po oblikah z akutom na dolžini; ${ }^{9}$ zgledi: (a) naglas na edinem zlogu osnove: b'rat brá:ta, y'rax yrá:xa 'fižol', x'lep xlé:ba, x'ram xrá:ma 'skedenj nad hlevom', x'ren xré:na, 'juh júrya 'južni veter', k'lin klí:na, 'Kuk Kú:ka, k'rux krú:xa, 'kup kú:pa, 'Lax Lá:xa 'Furlan, Italijan', 'las lá:za, 'mak má:ka 'mak, Papaver rhoeas', m'ras mrá:za, 'pič píčca 'kot', 'pux púxxa 'polh', 'pop pó:pa 'popek, umbilicus',

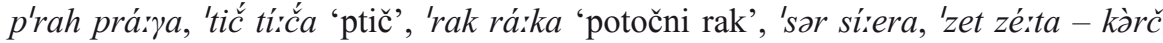

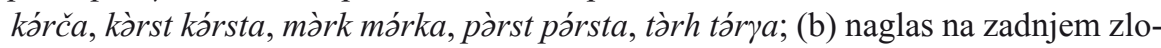
gu osnove: člo'vek človíreka, i'zik izíka, ka'̌̌ux kažú:xa, med'vet medvé:da, mače'rat mačerá:da, mod'ras modrá'sa, ob'ras obrá:za, op'len oplé:na 'neroden človek',

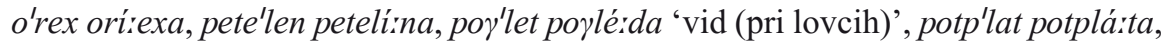
sano'sek sanosíreka 'kosec';10

< psl. *zuonbčítb *zuonbčîta (F) (> issln. *zuončit *zuončita > nad. zuon'čič zuončl čca); zgledi: samostalniki z naglašenimi tvornimi priponskimi obrazili: 1. nad. $-i \check{c}, \mathrm{knj}$. sln. $-i \check{c}<$ psl. *-itb s prvotnim pomenom manjšalnost v primeru, da po regularnem umiku naglasa $\mathrm{z}$ issln. *-ì na prednaglasno kračino prišlo do nalikovne izravnave naglasnega mesta po odvisnih sklonih: Var'tič Vartíč́a, uo $\gamma^{\prime} r i \check{c}$

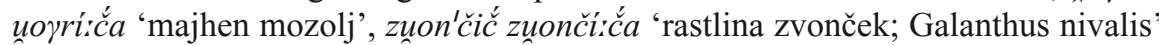

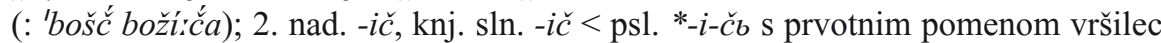
dejanja kot $\gamma r a$ 'bič yrabíča 'grabljač', mla'tič mlatí: ča;

< psl. *potòkb *potòka (a") (> issln. *potòk *potòka > nad. pa'tok patórka,

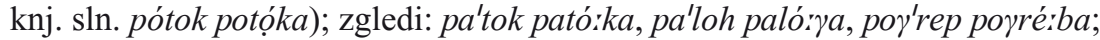

< psl. *studenb́cb *studèn b́ca (D) (> issln. *studenàc *studènca > nad. stu'denc studé:nca, $\geq \mathrm{knj}$. sln. studénac studénca), pri čemer je prišlo do naslednjih (naglasnih in nalikovnih) sprememb: 1. zgodnje podaljšanje issln. kratkih akutiranih zložnikov v nezadnjem besednem zlogu v zahodnih in južnih slovenskih narečjih; 2. nesplošni nadiški umik naglasa $\mathrm{z}$ issln. *-̀̀ na prednaglasni kratki samoglasnik v im./tož. ed.; 3. nalikovna razširitev cirkumfleksa na dolžini na osnovi v rod. mn. in or. mn. po vzoru issln. naglasnega tipa *kùp *kùpa ${ }^{11}$ zgled: stu'denc studé:nca;

9 Rigler 1970: 5-8.

${ }^{10}$ Samostalniki nad. x'lep xlé:ba, x'ren xré:na, med'vet medvé:da, op'len oplé:na v odvisnih sklonih izkazujeje nepričakovano samoglasniško kakovost za pričakovano nad. *ié$<$ issln. *è̀-, ki se pojavlja npr. v nad. člo'vek človíreka, o'rex orírexa, sano'sek sanosíreka.

${ }^{11}$ Nadiško narečje v tem primeru torej izkazuje pričakovani odraz prvotnega issln. naglasnega tipa, tj. issln. *studenàc *studènca $>$ studenäc studẹnca $>$ nad. studēnc studẹ́nca. Naglas v knj. sln. studénac studénca, nar. sln. studenäc studencä npr. v rez. (Korito) Stodo'nac, mest. ed. Stodon'ce (Dapit 1995: 190-191) kaže na to, da so v nekaterih drugih slovenskih narečjih samostalniki tega naglasnega tipa nalikovno prešli v issln. naglasni tip *loǹ̀c *loncà, pri čemer je do naglasnega stika med naglasnima tipoma prišlo v im. ed. 
$\leq$ psl. *perstòrz *perstòra (a") (> issln. *prě́stor *prěstòra $\geq$ nad. pres'tor prestó:ra, > star. knj. sln. préstor prestọ́ra (Pleteršnik)), pri čemer je prišlo do naslednjih (naglasnih in nalikovnih) sprememb: 1. zgodnje podaljšanje issln. kratkih akutiranih zložnikov v nezadnjem besednem zlogu v zahodnih in južnih slovenskih narečjih; 2. nalikovna posplošitev naglasnega mesta iz odvisnih sklonov v im. ed; 3. nalikovna razširitev cirkumfleksa na dolžini na osnovi v rod. mn. in or. mn. po vzoru issln. naglasnega tipa *kùp *kùpa; zgled: pres'tor prestó:ra 'prostor'; ${ }^{12}$

$\leftarrow$ prevzeto besedje:

(a) naglasno mesto je na edinem zlogu osnove: 'bank bá:nka 'lesena skri-

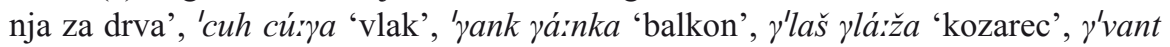

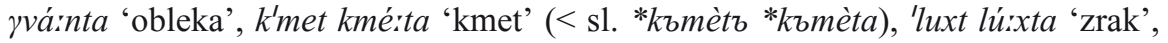
'mak má:ka ‘šop, grozd' (ヶ furl. mac ‘šop, sopek', Pirona 1992: 543), 'muš múiša 'osel', 'pek pérka 'pek', škaf škáifa, škof škó'fa, špal špá:la 'vrvica za šivanje', štix štíxa 'vzorec na pleteni jopi', 'uemp ué:mpa 'vamp';

(b) naglasno mesto je na zadnjem zlogu osnove: ele'fant elefá:nta star. 'slon', id'rik idríka 'redič', kanto'pet kantopé:ta 'gumijasta sponka za lase', ka'pot kapó:ta 'plašč', kos'tań kostá:ńa, li'vel livé:la 'ravnovesje', ma'nix ma'nixa 'redovnik' (< sl. *mъnïxъ *mъnïxa), no'vič novíča 'mladoporočenec', špar'jet šparyé:ta 'štedilnik', žu'pan župá:na ‘župan'.

\subsection{Tip klúúč klúúča}

Samostalniki naglasnega tipa klúuč klúuča imajo nepremični naglasni tip z akutom na osnovi, in sicer z naglasnim mestom na edinem/zadnjem ali nezadnjem zlogu osnove brez kolikostne premene in brez neobstojnega samoglasnika $\mathrm{v}$ im. ed. ali z njim. V večini sklonskih oblik poznajo akut na dolžini, v rod. mn., mest. mn. in or. mn. pa cirkumfleks na dolžini.

\begin{tabular}{|c|c|c|c|c|c|}
\hline klúúč & klíúča & kĺúču & $k l_{u} u ́ c ̌ c$ & klúưče & klúúčan \\
\hline klúúči & klìu:ču & klúučan & kliúče & klùu:čax & klúučmi \\
\hline klúúča & $=\mathrm{mn}$. & $=\mathrm{mn}$ & kĺúčca & $=\mathrm{mn}$ & $=\mathrm{mn}$ \\
\hline
\end{tabular}

Izvor:

< psl. *klúúčb *klúučà (b) (> issln. *klúuč *klúča > nad. klúưč klúuča , knj. sln. kljúč kljúča) po nalikovni razširitvi cirkumfleksa na dolžini na osnovi v rod. mn. in mest. mn. po vzoru issln. naglasnega tipa *kùp *kùpa; zgledi: naglasno mesto na edinem zlogu osnove: dríen dríena, yríex yríexa, yríč yríč́a 'kup kamenja, pobranega po senožeti ob trebljenju', xlí:eu xlí:eva, xló:t xló:da, Xú:m Xú:ma, xrí:p

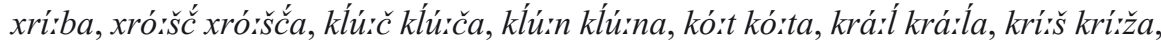
mlá:j mlá:ja, uóršs uórža 'gož', plá:šč plá:šča 'mašni plašč', pú:š pú:ža, ré:p ré:pa 'rep pri živali; dolgo in ozko zemljišče; pecelj pri jabolku', smírex smírexa, strí'c stríca, žá:r žá:ra 'žerjavica', žúíl žúla;

< psl. *messáríb *męsaŕá (B) (> issln. *męsár *męsára > nad. mesá:r mesá:rja, knj. sln. mesár mesárja); zgledi: češńík češńíka 'česen', čudá:k čudá:ka, rloniík

${ }^{12}$ Prvotni naglasni vzorec izkazuje star. knj. sln. prẹstor prestọ́ra (Pleteršnik). 
yloníkka 'glavnik', klabú:k klabú:ka, komárr komárrja, lažník lažníka 'lažnivec', lopá:r lopá:rja 'lopar pri kmečki peči', mexíer mexí:erja 'mehur, želodec', pastíer pastí:erja, roká:u roká:va, seni:k seníka, sərńá:k sərńáka, svetník svetni:ka; samostalniki s tvornimi naglašenimi priponskimi obrazili: 1. nad. -ar, knj. sln. - $a r<$ psl. *-aŕr s prvotnim pomenom opravkarja, tj. 'tisti, ki je v zvezi z': brusárr brusáarja 'brusač', dorvá:r dorvá:rja, yaspodá:r yaspodá:rja, klesá:r klesá:rja, kolá:r kolá:rja, mesá:r mesá:rja, pečárr pečáarja, sodá:r sodá:rja, tesá:r tesá:rja, zidá:r zidárrja; nalikovno se zaradi njegove tvornost $\mathrm{v}$ ta tip uvrstijo yovedárr yovedárrja 'pastir, ki pase govedo za celo vas', serárr serárrja 'sirar' za izvorno *gouęedaŕb *gouęedara, *sÿraŕb *sÿraŕa; 2. nad. -ač, knj. sln. -ač< psl. *-a-čb s prvotnim pomenom vršilca

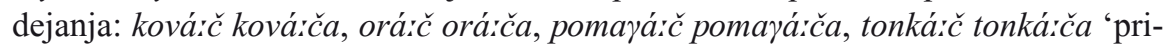
trkovalec';

< psl. *grobàŕr *grobàra (G) (> issln. *grobár *gorbáráa > nad. yrobá:r

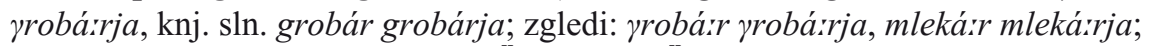

< psl. *äuorb *äuora (a), *uễdombcb *uếdombca (A) (> issln. *àuor *ànora, *uè̀domac *uè̀domca > nad. já:uor já:uorja, ví:edenc ví:edenca, $\mathrm{knj}$. sln. jávor jávo$r a$, vẹ́domac vẹ́domca), in sicer samostalnikov z naglasnim mestom na nezadnjem zlogu osnove; zgledi: naglasno mesto na nezadnjem zlogu osnove: díeluc díeluca, já:uor já:uorja, ká:men ká:mna, kú:ščer kú:ščerja, sé:ver sé:vera 'severni veter', víredenc víredenca 'vedomec';

< psl. *tráub́nikb *tráubinika (D) (> issln. *tráunik *tráunika > nad. trá:uenk trá:uenka, knj. sln. trávnik trávnika); zgledi: mócčenk mó:čenka, líešenk lí:ešenka, prá:zenk prá:zenka, trá:uenk trá:uenka;

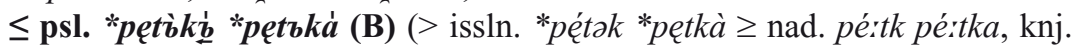
sln. pẹ́tək pẹ́tka) po posplošitvi naglasa im. ed. v stranskosklonske oblike in po nalikovni razširitvi cirkumfleksa na dolžini na osnovi v rod. $\mathrm{mn}$. in mest. mn. po

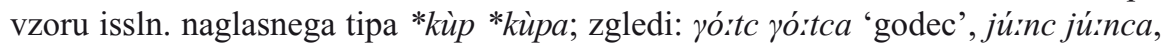
klá:nc klá:nca 'ograjena pot, po kateri se žene krave na pašo', Ní:emc Níemca, pé:tk péttka, píeuc pí:euca;

$\leq$ psl. *suếdrb *suễdra (a) (> issln. *suẽdar *suè̀dra $\geq$ nad. sví:edar sví:edra, knj. sln. svẹ́dər svẹ́dra) po posplošitvi naglasa oblik z akutom na kračini; zgledi: yá:bar yá:bra, ká:šel ká:šla, svíiedar svíedra;

$\leq$ psl. *zädbkb *zädъka (A) (> issln. *zàdək *zâdka $\geq$ nad. zá:tk zá:tka, knj. sln. zâdək zâdka), ko je prišlo do posplošitve naglasa iz oblik z akutom na kračini; zgled: zá:tk záitka 'čep pri sodu';

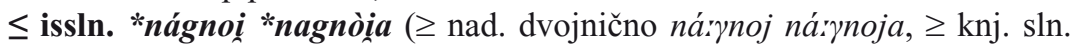
nagnöj nagnója), po posplošitvi naglasa im. ed. v stranskosklonske oblike; zgledi:

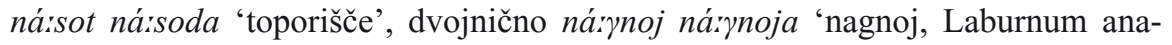
gyroides';

$\leftarrow$ prevzeto besedje:

(a) naglasno mesto je na edinem zlogu osnove: cárjt cáijta 'čas', fárjt fáijta 'vlaga', pá:l pá:la 'drog' (npr. pá:l za elè:triko 'drog za elektriko'), píli píla 'kip svetnika', ráajšs rá:jža 'riž', só:ut sóruda 'denar'; cú:kar cú:kra 'sladkor', já:yar já:rra 'lovec', má:len má:lna 'mlin' (< sl. *mb̀linъ *mb̀lina); 


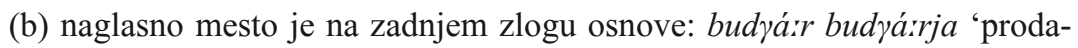
jalec v trgovini', cesá:r cesárrja, čebelárr čebelá:rja 'čebelar’ ( $\longleftarrow \mathrm{knj}$. sln. čabelár : Jevšček bušè:la 'čebela'), fornažá:r fornažá:rja 'opekar', krampírer krampí:erja, malovárr malovárrja 'zidarjev pomočnik', marčúíl marčúĺa 'manjše kladivo', meští:er meští:erja 'poklic', ojcetá:r ojcetá:rja 'svat', oští:er oští:erja 'gostilničar', ožé:jt ožé:jda 'kis', rezervá:r rezervá:rja, ormá:r ormá:rja 'omara', rožá:r rožá:rja 'rožni venec', sodník sodníka 'sodnik' ( $\leftarrow$ knj. sln. sodnik), solárr solárrja 'podstrešje’, vojá:k vojá:ka novejše 'vojak’ ( $\leftarrow$ knj. sln. voják: Jevšček sudà:t starejše 'vojak');

(c) naglasno mesto je na nezadnjem zlogu osnove: á:jer á:jerja star. 'zrak', címbar cí:mbarja 'renkloda, ringlo', é:jsix é:jsixa star. 'kis', ké:nar ké:narja 'natakar', mé:žnar mé:žnarja 'cerkovnik', pé:tlar pé:tlarja 'berač', puló:var pulórvarja, vírertux vírertuxa 'predpasnik'; fá:moštor fá:moštra 'župnik'; krá:ncul krá:culna 'venec'.

\subsection{Tip kù̀os kùrosa}

Samostalniki naglasnega tipa kùoos kù̀osa imajo nepremični naglasni tip s cirkumfleksom na osnovi. V vseh sklonskih oblikah je cirkumfleks na dolžini na osnovi.

\begin{tabular}{|c|c|c|c|c|c|}
\hline kùios & kùyosa & kù'osu & kùrosa & kùrose & kùrosan \\
\hline kù'osi & kù:osu & kùrosan & kùrose & kùrosax & kùrosmi \\
\hline kùrosa & $=\mathrm{mn}$. & $=\mathrm{mn}$. & kùrosa & $=\mathrm{mn}$ & $=\mathrm{mn}$. \\
\hline
\end{tabular}

Izvor:

< psl. *mễsęcb *mễsęca, *cễstaŕb *cễstaŕa (A) (> issln. *me̊sęc *mêsęca, *cêstar *cêstaŕa > nad. mìresc mì'esca, cìrestar cì'estarja, knj. sln. mệsec mệseca, cệstar cệstarja); zgledi: yrà:bĺar yrà:bĺarja 'izdelovalec grabelj’, xòsstar xò̀starja 'gozdni delavec', jàsstrep jàsstreba, kosìščar kosìščarja 'izdelovalec kosišč', mìesc mìesca, pàilk pàılka 'pajek', rì̀bar rìbarja redko 'ribič' (: običajno peškatòrr), zèrjc zè̀jca; mìšsenk mì̌šenka 'past za miši'; cìestar cì'estarja;

< psl. *uëčerb *uëčera (c) (> issln. *uečêr *uečêra > nad. večèrr večèrra, knj. sln. vecệr večêra), pri čemer je prišlo do posplošitve naglasa oblik s cirkumfle-

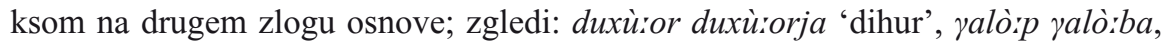

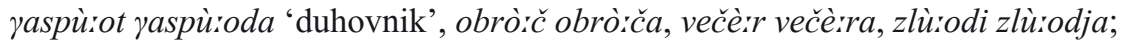

$\leq$ psl. *kösъ *kösa (c) (> issln. *kôs *kosâ $\geq$ nad. kù'os kùuosa, knj. sln. kộs $k \hat{o} s a$ ), pri čemer je prišlo do posplošitve naglasa im. ed. oz. naglasa predložnih edninskih stranskosklonskih oblik; zgledi: brìrest brì'esta, kùros kùrosa, lìst lìssta, tù:or tù'ora 'tvor, izpuščaj', žìer žìera;

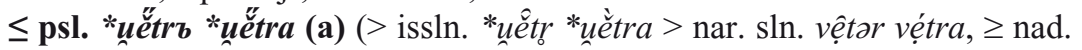
vìetar vìetra, $\geq \mathrm{knj}$. sln. vệtər vệtra), pri čemer je prišlo do posplošitve naglasa oblik s cirkufmleksom na dolžini;

$\leq$ psl. *stärbcb *stärbca (A) (> issln. *stàrac *stârca $\geq$ nad. stàrrc stà'rca, knj. sln. stârac stârca), pri čemer je prišlo do posplošitve naglasa stranskosklonskih

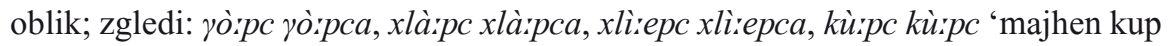
sena', mazìnnc mazìnnca, pà:unc pà:uca, pjà:nc pjà:nca, stàrrc stàrrca, želòrc želòrca; 


\section{$\leftarrow$ prevzeto besedje:}

(a) naglasno mesto je na edinem zlogu osnove: à'uto àruta, pùrop pùroba;

(b) naglasno mesto je na zadnjem zlogu osnove: advokà:t advokà:ta 'odvetnik, advokat', batò'n batò:na 'gumb', butilònn butilò:na 'dvolitrska steklenica', čamìn čamìna 'dimnik', cempìnn cempì:na 'cepin', kàınker kà:nkerja star. 'rak, karcinom', kantò'n kantò:na 'vogal', kaštrò̀n kaštrò:na 'oven', klintò:n klintò:na 'vino iz klinte, sorte vinske trte', kuartìn kuartìna 'štirje decilitri', madrò:n madrònna 'trebuh', mà̀lar mà:larja 'pleskar', peškatòrr peškatò:rja 'ribič', roplà:n roplà:na 'letalo', sudà:t sudàrta starejše 'vojak', žefrà:n žefrà:na;

(c) naglasno mesto je na nezadnjem zlogu osnove: cì:mporman cì:mpormana 'tesar ostrešja', dòxtar dòxxtarja 'zdravnik', yù:lcar yù:lcarja 'sezonski gozdni delavec', kaplàın kaplà:na 'kaplan', pù̀oštar pù̀oštarja, rù̀ksak rù:ksaka 'nahrbtnik', šùroštar šùroštarja 'čevljar', špìunenk špìuenka 'sveder', tì̌šler tìšĺerja 'mizar', trenìn trenìna 'manjši vlak, ki je po prvi svetovni vojni vozil na relaciji Kobarid Čedad', učìtel uč̀̀telna ( $\leftarrow$ knj. sln. učîtelj), ù.rlaup ù:rlaupa star. 'vojaški dopust v Avstro-Ogrski', žnìdar žnìdarja 'krojač';

$\leftarrow$ hibridne tvorbe:

(a) prevzeta besedotvorna podstava in podedovano priponsko obrazilo: nad. -ar: bò:tar bò:tarja 'škornjar kot poimenovanje za nemške vojake' iz bò:te 'škornji', kontobà:ntar kontobà:ntarja 'tihotapec', kù.otar kù'otarja 'ogljar' iz kù'ota 'ogljarska kopa', kùxxar kùxxarja iz kúxxat kùxxan, mlìnnar mlìnarja, pùroštar pùroštarja 'poštar, pismonoša' iz pùrošta 'pošta ', šùrolar šùrolarja 'šolar, učenec' iz šùuola 'šola', ${ }^{13}$

(b) podedovana ali prevzeta besedotvorna podstava in prevzeto priponsko obrazilo: 1. nad. -ì:n prvotno s pomenom manjšalnosti: mačkìn mačkìna 'majhen maček', pedì'n pedìna 'razdalja med palcem do mezincem na roki', praščìnn praščìna 'majhen prašič', repulìn repulìna 'polh', sakolìn sakolì:na 'majhen

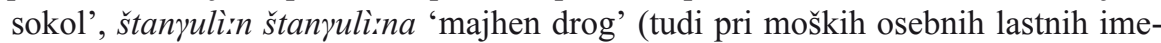
nih Lojzìn Lojzìna, Pepìn Pepi:na, Toncìn Toncìna); 2. nad. -ò:n s pomenom večalnosti: flaškò:n flaškò:na 'petlitrska ali večja pletenka', unikalna komponenta *kačònn samo v frazemu strupè:n ku kačònn.

\subsection{Tip sórset sosí:eda}

Samostalniki naglasnega tipa sósset sosí:eda imajo premični naglasni tip. V večini sklonskih oblik poznajo akut na dolžini, v im. ed. dolžino ali kračino, v rod. mn. in or. mn. pa cirkumfleks na dolžini.

\begin{tabular}{|llllll|}
\hline sórset & sosíreda & sosíredu & sosíeda & sosírede & sosíredan \\
sosíredi & sosìredu & sosíredan & sosíede & sosíredax & sosìredmi \\
sosíreda & $=\mathrm{mn}$. & $=\mathrm{mn}$. & sosíeda & $=\mathrm{mn}$. & $=\mathrm{mn}$. \\
\hline
\end{tabular}

${ }^{13}$ Izpeljanke kûhar, pộštar, šộlar so najverjetneje tvorjene v slovenščini na osnovi iz nemščine prevzetih besedotvornih podstav (kúhati, pộsta, šộla). Na domačo tvorbo bi npr. kazala za podedovano besedje značilna naglasna premena kúhati : kûhar. Tudi Stridter-Temps 1963 naštetih besed ne navaja med iz nemščine prevzetimi besedami. Ni pa mogoče popolnoma izključiti, da vsaj katera v slovenščino ni bila prevzeta že kot izpeljanka ali pa tvorjena po tujejezičnem modelu (sln. šộla $\rightarrow$ šộlar, srvn. schuole $\rightarrow$ schuolære, nem. Schule $\rightarrow$ Schüler). 
Izvor:

< psl. *nagnòib *nagnòia (a") (> issln. *nágnoi *nagnòia > nad. dvojnično

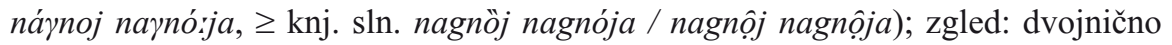

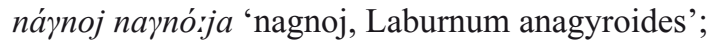

< psl. *božlitb *božîta (F) (> issln. *božit *božita > nad. bošč božíč́a, knj. sln. bóžič božiča), pri čemer je v narečju prišlo do naglasnega umika z issln. *-ì na prednaglasno kračino po regularnem naglasnem umiku ('bošč božlič́a, substratno krajevno ime Ko'bart Kobarí:da);

$\leq$ psl. *terbüxx *terbüxa (a) ( $>$ issln. *trěbùx *trěbùxa $\geq$ nad. trí:ebux trebú:xa, $\geq$ knj. sln. trẹ́buh trebúha), pri čemer je prišlo do naglasnega umika na prednaglasno dolžino, ki je po naglasnem pravilu nepričakovana (sóset sosíreda, trí:ebux trebú:xa). ${ }^{14}$

\subsection{Tip 'koń ko'ńa}

Samostalniki naglasnega tipa 'koń ko'ńa imajo končniški naglasni tip. Delijo se na dva podtipa: 1. podtip brez neobstojnega samoglasnika v im. ed.: 'koń ko'ńa; 2. podtip z neobstojnim samoglasnikom $\mathrm{v}$ imenovalniku ednine (in s premeno $u$ : l, ko se pojavlja neobstojni $u$ ): če bor čeb'ra, ske'deń sked'ńa, štérrem šter'ma 'vodnjak brez izvira', ko'tu kot'la. Naglašena končnica je v večini sklonskih oblik kratka, v rodilniku množine dolga in cirkumflektirana, v orodniku množine dolga in akutirana. Nekateri samostalniki imajo v mestniku ednine poleg naglasa na končnici tudi naglas na osnovi, in sicer se pojavlja akut na dolžini ('ta Par párče, 'du pá:kle, 'du várte).

Poseben sklanjatveno-naglasni vzorec pozna samostalnik ot'rok otro'ka, in sicer z naslednjimi odstopanji od vzorca 'koń ko'ńa: 1. im. mn.: ničta končnica in kratki naglas na osnovi; 2. rod. mn.: ničta končnica in naglas na osnovi (akut na dolžini); 3. mest. mn.: končnica -ex in naglas na osnovi (akut na dolžini); 4. or. mn.: naglas na osnovi (akut na dolžini). Sklonske oblike rod. mn., mest. mn. in or. mn. poznajo samoglasniško premeno $o:$ uio $\mathrm{v}$ zadnjem zlogu osnove, obliki im. mn. in mest. mn. pa soglasniško premeno $k: c$.

(a) Tip 'koń ko'ńa

\begin{tabular}{|llllll|}
\hline 'koń & ko'ńa & ko'ńu & ko'ńa & ko'ńe & ko'ńan \\
ko'ńi & końò:u & ko'ńan & ko'ńe & ko'ńax & końmí: \\
ko'ńa & $=\mathrm{mn}$. & $=\mathrm{mn}$. & ko'ńa & $=\mathrm{mn}$. & $=\mathrm{mn}$. \\
\hline
\end{tabular}

${ }^{14}$ Praslovanski prednaglasni dolgi samoglasniki: 1. se skrajšajo v psl. trizložnicah z naglasom na (psl. staroakutiranem ali psl. novoakutiranem) dolgem srednjem samoglasniku: nad. i'zik izi:ka, knj. sln. jézik jezika, čak. jazïk jazïka, nštok. jèzik jèzika, češ. jazyk

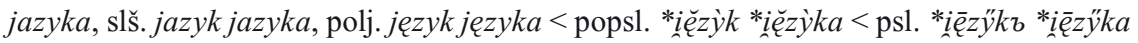
(a); 2. se ne krajšajo v psl. trizložnicah z naglasom na kratkem srednjem samoglasniku (naglasa sta psl. novi akut na kračini ali psl. naglas tipa novega akuta na kračini): nad.

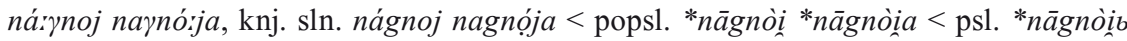
*nāgnòia $\left(\mathrm{a}^{\prime \prime}\right)$. 
(b) Samostalnik ot'rok otro'ka

\begin{tabular}{|llllll|}
\hline ot'rok & otro'ka & otro'ku & otro'ka & otro'ke & otro'kan \\
ot'roc & otrú'ok & otro'kan & otro'ke & otrú:ocex & otrú:okmi \\
otro'ka & $=\mathrm{mn}$. & $=\mathrm{mn}$. & otro'ka & $=\mathrm{mn}$. & $=\mathrm{mn}$. \\
\hline
\end{tabular}

Izvor:

< psl. *kòńíb *końá, *bb̀t 'koń ko'ńa, 'bat ba'ta, knj. sln. könj kónja, bät bətä / bät bàta); zgledi: 'bat ba'ta 'bet, večje kladivo; živinska muha', pa'ku pak'la - 'bop bo'ba, 'čep če'pa 'čep pri sodu',

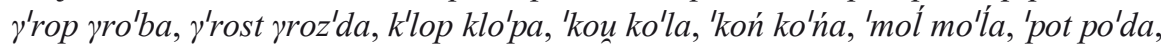
s'nop sno'pa, s'tou sto'la 'stol brez naslonjala, npr. za molžo' (: kandrè:ja 'stol z naslonjalom, npr. za jedilno mizo'), st'rop stro'pa, 'uou uo'la - kàrt kar'ta, pàrt par'ta,

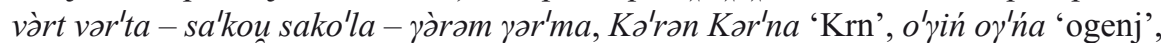
ta'ran tor'na;

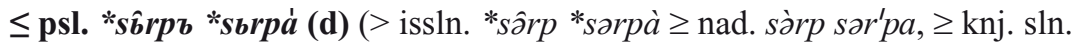
sârp sârpa), tj. odraz psl. naglasnega tipa d pri samostalnikih s praslovansko dvoglasniško zvezo *TbrT/*TъrT v osnovi; zgleda: sàrp sər'pa, vàrx var'xa;

Izhodiščni splošnoslovenski naglasni tip issln. *kòn *końà je doživel naslednje nalikovne spremembe: 1 . v rodilniku množine je bila prvotna ničta končnica nadomeščena s končnico - ò:u, posplošeno iz praslovanske $u$-jevske sklanjatve; 2 . v mestniku in orodniku množine je prišlo do nadomestitve naglasa na osnovi s končniškim naglasom po vzoru ostalih oblik s končniškim naglasom. Podedovano oblikovno in naglasno stanje $\mathrm{v}$ rodilniku, mestniku in orodniku množine (v slednjem samo prvotno naglasno stanje, saj je bila prvotna končnica *-y nadomeščena s končnico *-bmi/*-bmi) izkazuje samostalnik ot'rok otro'ka (nad. otrú:ok, otrú:ocex, otrú:okmi, knj. sln. otrọ́k, otrọ́cih, otrọ́ki < issln. *otrók, *otrócěx, *otróki < psl. *otròkz, *otròcéxz, *otròky). ${ }^{15}$ Prvotno nadiško naglasno stanje, tj. umik naglasa z izhodiščnega splošnoslovenskega *-ì na prednaglasno kračino ohranja imenovalnik množine (nad. ot'roc < issln. *otroci $<$ psl. *otroci).

Naglas na osnovi v mestniku ednine v oblikah kot 'ta Par pá:če, 'du pá:kle, 'du várte je najverjetneje nalikoven. Nastal bi lahko po vzorcu naglasa v mestniku množine znotraj odrazov samostalnikov praslovanskega naglasnega tipa b s kratkim zložnikom v zadnjem/edinem zlogu osnove: nad. 'du pákle $<*$ dols uz pb̀klě $\leq$ psl. *dolı uъ pbklè̀ po vzoru nad. otrú:ocex, knj. sln. otrọ́cih < psl. *otròcěxъ. V nadiškem narečju je naglas na osnovi v mestniku ednine torej ohranjen samo kot relikt pri pogosto rabljenih samostalnikih, ki se zaradi svojega leksikalnega pomena pogosto pojavljajo v stavčnočlenski vlogi prislovnega določila kraja, medtem ko je

${ }^{15}$ Praslovanski novi akut na kračini je pri samostalnikih $o$-jevske sklanjatve naglasnega tipa b nastal: 1 . v rodilniku množine po naglasnem umiku s praslovanskega polglasnika v šibkem položaju: psl. *otròkъ < *otrokb (Ivšić 1911); 2. v mestniku množine po naglasnem umiku s praslovanskega starocirkumflektiranega srednjega zloga po Ivšić-Stangovem zakonu: psl. *otròcěxъ < *otrocếx (Ivšić 1911; Stang 1957); 3. v orodniku množine nalikovno po naglasu mestnika množine (oba sklona se večinoma rabita predložno za izražanje prislovnega določila kraja): psl. *otròky $\leq{ }^{*}$ otroký. 
pri večini samostalnikov s končniškim naglasom prišlo tako v ednini kot v množini do posplošitve naglasa na končnici. ${ }^{16}$ Vsaj za del slovenskih narečij lahko torej sklepamo, da so imela prvotno naglas na osnovi v mestniku in orodniku tako v množini kot $\mathrm{v}$ ednini. Smer delovanja nalike je torej bila naslednja: Lpl *kónixz, Ipl *kóńi $\rightarrow$ Lsg *końi, Isg *końémb $\geq$ Lsg *kòni, Isg *kònemb. Razlika med množinskimi in edninskimi oblikami je $\mathrm{v}$ tem, da prvi izkazujeta izhodiščno splošnoslovensko dolžino, medtem ko drugi kažeta na izhodiščno splošnoslovensko kračino.

< psl. *lonb̀cb́ *lonbcá (B) (> issln. *lonàc *loncà > nad. 'lonc lon'ca, knj. sln. lónəc lónca), in sicer samostalniki z osnovo ne na zvočnik, pri katerih posledično pride do umika naglasa $\mathrm{z}$ issln. *-̀̀ na prednaglasni kratki samoglasnik v im. ed.; zgledi: ka'zouc kazou'ca, k'louc klou'ca 'klobčič', 'konc kon'ca, 'korc kor'ca, 'lonc lon'ca, z'uonc zuon'ca 'kravji zvonec' - 'ous ou'sa;

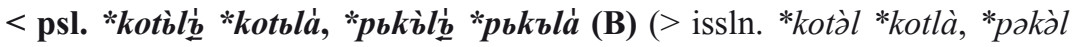
*pəklà > nad. ko'tu kot'la, pa'ku pak'la, knj. sln. kótəl kótla, pakäl pəklä / pàkal pàkla), in sicer samostalniki z osnovo na zvočnik, pri katerih posledično ne pride do umika naglasa $\mathrm{z}$ issln. *-̀े na prednaglasni kratki samoglasnik v im. ed.; zgledi: ko'tu kot'la, o'ru or'la, pa'ku pak'la - če $e^{\prime} b \partial r$ čeb'ra;

$\leftarrow$ prevzeto besedje:

(a) samostalniki brez neobstojnega samoglasnika $\mathrm{v}$ im. ed.: b'lek ble'ka 'krpa, zaplata', f'lok flo'ka 'metuljček pri moški obleki', 'mošt moš'ta, 'pač pa'ča 'vodnjak z izvirom', p'lex ple'xa 'pločevina', špex špe'xa, š'pot špo'ta 'sram', štor što'ra, 'žek $\check{z} e^{\prime} k a$ 'pletena nogavica';

(b) samostalniki z neobstojnim samoglasnikom v im. ed.: ske'deń sked'ńa, šté:rem šter'ma 'vodnjak brez izvira';

$\leftarrow$ hibridne tvorbe; zgled: 'norc nor'ca 'norec'. ${ }^{17}$

\subsection{Tip mò̀š možàr}

Samostalniki naglasnega tipa mòrš možàr, zì̀t zidùr imajo mešani naglasni tip. Naglas je v manjšem številu sklonskih oblik na osnovi, v večini oblik pa na končnici. Na osnovi se pojavlja cirkumfleks na dolžini (im. ed., dvojnično daj. ed., or. ed.) ali akut na dolžini (mest. ed.). Naglašene končnice so vse dolge, in sicer cirkumflektirane (rod. ed., dvojnično daj. ed., im. mn., tož. mn., daj. mn.) ali akutirane (rod. mn., mest. mn., or. mn.). Samostalniki s podspolom živo imajo v daj. ed. večinoma

${ }^{16}$ Naglas na osnovi v mestniku kot tudi v orodniku ednine pri samostalnikih praslovanskega naglasnega tipa b s kratkim zložnikom v zadnjem/edinem zlogu osnove pozna npr. tersko narečje: ter. (Subid) 'koń ko'ńa : na kó:ńu, s kó:ńan (Bruna Balloch, roj. 1935, ustno).

${ }^{17}$ Nadiško narečje izkazuje končniški naglasni tip noräc norcä, ki je najverjetneje drugoten, in sicer je nastal po vzoru im. ed. za prvotno issln. *noräc *nōrca $<$ sl. *norb́cb

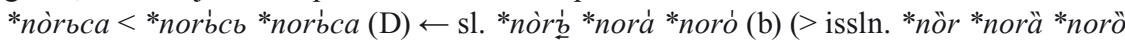
$>$ nad. 'nor no'ra no'ro, rez. (Bila) 'nọr no'ra no'rọ). Prvotni naglasni tip s popraslovanskim daljšanjem praslovasnkih kratkih akutiranih zložnikov v zlogu pred praslovanskim polglasnikom v šibkem položaju v tem leksemu izkazuje npr. rezijansko narečje: rez. (Bila) 'mẹt za 'nurcạ 'imeti za norca' < issln. *nōrca. Prim. tudi rez. (Bila) griz'duję <

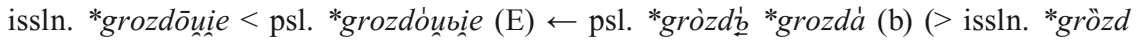
*grozdà > rez. (Bila) g'rost groz'dạ). 
naglas na končnici (možùu, ukùi), samostalniki s podspolom neživo pa naglas na osnovi (zi:du). Do naglasnomestne premene pri cirkumfleksu na dolžini v položajih oblika brez predslonke : oblika s predslonko prihaja redko (breyùr: $z$ brìreya u brì̀eh, dobà̀/dobùr: : $z$ dò̀ba).

(a) Samostalniki s podspolom živo

\begin{tabular}{|c|c|c|c|c|c|}
\hline $\begin{array}{l}\text { mò丶šs } \\
\text { možìe } \\
\text { možà: }\end{array}$ & $\begin{array}{l}\text { možàr } \\
\text { možĺr } \\
=\mathrm{mn} .\end{array}$ & $\begin{array}{l}\text { možù: } \\
\text { možè:n } \\
=\text { mn. }\end{array}$ & $\begin{array}{l}\text { možàa: } \\
\text { možè: } \\
\text { možàa }\end{array}$ & $\begin{array}{l}\text { mó:že } \\
\text { možíex } \\
\text { = mn. }\end{array}$ & $\begin{array}{l}\text { mò:žan } \\
\text { možmí: } \\
=\mathrm{mn} .\end{array}$ \\
\hline
\end{tabular}

(b) Samostalniki s podspolom neživo

\begin{tabular}{|c|c|c|c|c|c|}
\hline $\begin{array}{l}\text { zì̀t } \\
\text { zidìe } \\
\text { zidà: }\end{array}$ & $\begin{array}{l}\text { zidùr } \\
\text { zidí: } \\
=\mathrm{mn} .\end{array}$ & $\begin{array}{l}\gamma \text { zì:du } \\
\text { zidè:n } \\
=\mathrm{mn} .\end{array}$ & $\begin{array}{l}\text { zìt } \\
\text { zidì: } \\
\text { zidà: }\end{array}$ & $\begin{array}{l}\text { zíde } \\
\text { zidíex } \\
=\mathrm{mn} .\end{array}$ & $\begin{array}{l}\text { zirdan } \\
\text { zidmi: } \\
=\mathrm{mn} .\end{array}$ \\
\hline
\end{tabular}

Izvor:

< psl. *môz̆b̆ *môz̆a (c) (> issln. *môž *mQžâa > nad. mò̀š možàa, knj. sln. môž

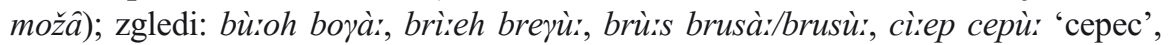

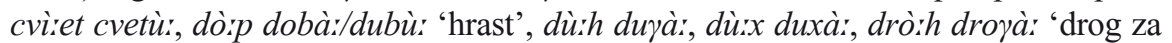

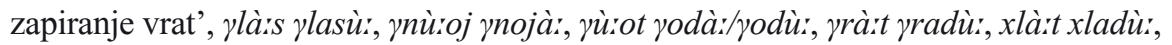
ì'es jezùr, klàrs klasùr, krìres kresùr, làrn lanù', làrs lasùr, lè̀t ledùr, lìres lesùr, lùroj lojùi, lò̀k lokùi 'lok mavrice', màxx maxù', mè̀t medùi, mì'ex mexù: 'kovaški meh; ovčja koža za shranjevanje pšenice', mìrer merù', mlàst mlatù: 'cepec', mùrost mostùi, mòrš možàr, mràrk mrakùr, nù'os nosùr : z nùrosa, pà̀ń pańùr 'čebelji panj; stojalo za drva na ognjišču', plàrs plazùi', plùrot plotùr: : ot plùrota, pùrot potùr, prà:x praxù:, plèss plesù', prò̀t protù', pùrst pustà: 'pust, pustna šema', rè̀t redùr', rò:p robù: 'rob;

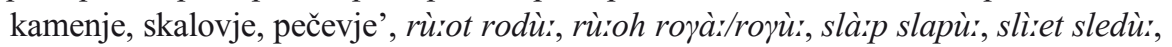

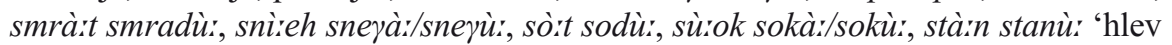
v planini', strà:x straxù: 'strah; strašno bitje', strò:x stroxù: 'strok (česna)', strù:p strupà', svì̀et svetù', tà̀t tatù', trà̀k trakù', trù:p trupà: 'trup pri živali', ù:k ukà: 'volk', ùros uozà', urà̀t uratùr 'vrat; gnojen travnik', zì̀t zidùi, zò̀b zobàr, zrà̀:k zrakù', zùron zuonà:, žlìep žlebù: - samomnožinska samostalnika drožìe, oldìe.

Izhodiščni splošnoslovenski naglasni tip issln. *lês *lěsâ je doživel naslednje nalikovne spremembe: 1 . v dajalniku ednine je pri samostalnikih s podspolom živo prišlo do posplošitve naglasa v položaju ne za enozložno predslonko, pri samostalnikih s podspolom neživo pa naglasa v položaju za enozložno predslonko; 2 . v mestniku ednine se pojavlja akut na dolžini na osnovi, katerega nastanek z diahronega vidika ni povsem jasen; 3. v orodniku ednine se je posplošil naglas v položaju za enozložno predslonko; 4. v dajalniku množine se pojavlja odraz praslovanskega starega cirkumfleksa na osnovi, najverjetneje pod vplivom naglasa v ednini. Ostale sklonske oblike nadaljujejo izhodiščno splošnoslovensko naglasno stanje.

< psl. *nögъtb *nögъti (c) (> issln. *nogât *noxtâ > nad. noxà:t noxtù:, $\geq$ knj. sln. nộht nộhta).

$\leftarrow$ prevzeto besedje: lòrr lorù: 'cev', tràrm tramùi. 


\section{Zaključek}

Zgodovinskojezikoslovna interpretacija sklanjatve in naglasa samostalnikov moške $o$-jevske sklanjatve v krajevnem govoru vasi Jevšček pri Livku nadiškega narečja slovenščine prinaša vsaj dve spoznanji, pomembni za (primerjalno)zgodovinsko oblikotvorje in naglasoslovje slovenščine.

$\mathrm{V}$ nadiškem narečju odrazi samostalnikov praslovanskega naglasnega tipa c v množini v večini sklonskih oblik izkazujejo odraze končnic praslovanske moške $i$-jevske sklanjatve (Npl glasjệ < *-bie, Gpl glasi < *-bibb, Apl glasî < *-i, Ipl glasmí

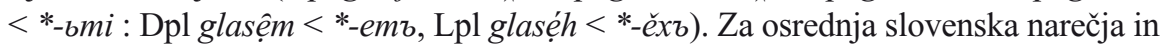
slovenski knjižni jezik je tovrstni naglasno-sklanjatveni vzorec značilen le za odraz samomnožinskega samostalnika praslovanske moške $i$-jevske sklanjatve ljudjệ (in sicer ljudjệ, ljudì, ljudẹm, ljudî, ljudẹh, ljudmí), z izjemo rodilnika in tožilnika množine pa še za nekaj samostalnikov (knj. sln. lasjẹ, možjệ, zobjệ, dvojnično še tatộvi/tatjệ, vozộvi/vozjệ; volkộvi/volcjệ) (in sicer lasjệ, lás, lasệm, lasệ, lasẹh, lasmi) kot tudi nekaj reliktnih oblik (Apl dolgệ, Lpl bregẹh). Nadiško gradivo bi torej kazalo na to, da je bil pri samostalnikih moške $o$-jevske sklanjatve z mešanim naglasnim tipom naglasno-sklanjatveni vzorec tipa lâs lasû, Npl lasjệ v slovenščini v preteklosti bolj razširjen in da ga je šele kasneje izpodrinil naglasno-sklanjatveni vzorec samostalnikov praslovanske (moške) $u$-jevske sklanjatve tipa sin sinû, Npl sinộvi.

$\mathrm{V}$ nadiškem (in terskem) narečju izkazujejo odrazi samostalnikov praslovanskega naglasnega tipa b s kratkim zložnikom v zadnjem/edinem zlogu osnove v mestniku (in orodniku) ednine podobno kot v mestniku in orodniku množine ostanke naglasa na osnovi (könj konjä ... : Lsg kọnju, Isg kọ́njem, Lpl kọnjih, Ipl kọ́nji). Odraz praslovanskega novega akuta na kračini v zadnjem/edinem zlogu osnove v mestniku in orodniku ednine je najverjetneje nastal po vzorcu prvotnega praslovanskega novega akuta na kračini (z zgodnjo popraslovansko podaljšavo) v zadnjem/ edinem zlogu osnove $\mathrm{v}$ mestniku in orodniku množine. Medtem ko množinski obliki izkazujeta izhodiščno splošnoslovensko dolžino, edninski obliki kažeta na izhodiščno splošnoslovensko kračino. Posledično torej lahko vsaj za del slovenskih narečij rekonstruiramo prvotni končniški naglasni tip z naglasom na osnovi v mestniku in orodniku ednine in množine (sln. ednina *kòn, *końà, *końù, *końà, *kòni, *kònem, množina *końi, *kóń, *końèm, *końę, *kóńix, *kónii), če ne že za celotno slovensko jezikovno ozemlje.

\section{Krajšave}

A/tož. = akuzativ/tožilnik, D/daj. = dativ/dajalnik, du/dv. = dual/dvojina, G/rod. = genitiv/rodilnik, knj. = knjižno, I/or. = instumental/orodnik, issln. = izhodiščni splošnoslovenski, L/mest. = lokativ/mestnik, N/im. = nominativ/imenovalnik, nad. $=$ nadiško, nadiško narečje, nar. = narečno, $\mathrm{pl} / \mathrm{mn} .=$ plural $/ \mathrm{množina,} \mathrm{psl} .=$ praslovansko, praslovanščina, rez. = rezijansko, rezijansko narečje, sg/ed. = singular/ ednina, sl. = slovansko (tj. zgodnje slovansko), sln. = slovensko, slovenski jezik, star. $=$ starejše 


\section{Literatura}

Bezlaj 1976-2007 = France Bezlaj, Etimološki slovar slovenskega jezika 1-5, Ljubljana, 1976-2007.

Dapit 1995-2008= Roberto Dapit, Aspetti di cultura resiana nei nomi di luogo 1: Area di Solbica/Stolvizza e Korïto/Coritis; 2: Area di Osoanë/Oseacco e Učja/Uccea; 3: Area di Bila/San Giorgio, Njüwa/Gniva e Ravanca/Prato. Padova, 1995-2008.

Dybo 1981 = Владимир Антонович Дыбо, Славянская акиентология, Москва, 1981.

Dybo 2000 = Владимир Антонович Дыбо, Морфологизованные парадигматические акиентные системы, Москва, 2000.

Dybo - Zamjatina - Nikolajev 1990 = Владимир Антонович Дыбо - Галина Игоревна Замятина - Сергей Львович Николаев, Основы славянской акиентологии, Москва, 1990.

Dybo - Zamjatina - Nikolajev 1993 = Владимир Антонович Дыбо - Галина Игоревна Замятина - Сергей Львович Николаев, Основы славянской акцентологии: словарь: непроизводные основы мужского рода 1, Москва, 1993.

Ivšić 1911 = Stjepan Ivšić, Prilog za slavenski akcenat, Rad Jugoslavenske akademije znanosti i umjetnosti (Zagreb) 187 (1911), 3-207.

Logar 1974 = Tine Logar, Pregled zgodovine slovenskega jezika, Seminar slovenskega jezika, literature in kulture: zbornik predavanj 9 (1974), 103-113. Ponatis: Logar 1996: 331-336.

Logar 1996 = Tine Logar, Dialektološke in jezikovnozgodovinske razprave, ur. Karmen Kenda-Jež, Ljubljana, 1996.

Pirona 1992 = Giulio Andrea Pirona idr., Il nuovo Pirona: vocabolario friulano, aggiunte e correzioni riordinate da Giovanni Frau per la seconda edizione, Udine, ${ }^{2} 1992$ (2004, $\left.{ }^{1} 1928\right)$.

Pleteršnik = Maks Pleteršnik, Slovensko-nemški slovar: transliterirana izdaja, Ljubljana, 1894-1895 (2006) [elektronska različica].

Ramovš 1950 = Fran Ramovš, Relativna kronologija slovenskih akcentskih pojavov, Slavistična revija (Ljubljana) 3 (1950), 16-23.

Ramovš 1952 = Fran Ramovš, Morfologija slovenskega jezika, Ljubljana, 1952.

Rigler 1970 = Jakob Rigler, Akcentske variante I, Slavistična revija (Ljubljana) 18 (1970), 5-15.

Rigler 1971 = Jakob Rigler, Akcentske variante II, Slavistična revija (Ljubljana) 19 (1971), 1-12.

Rigler 1977 = Jakob Rigler, K problematiki daljšanja starega akuta, Slavistična revija (Ljubljana) 25 (1977), 83-99.

Rigler 1978 = Jakob Rigler, Akcentske variante III, Slavistična revija (Ljubljana) 26 (1978), 365-374.

SP 2001 = Slovenski pravopis, Ljubljana, 2001.

SSKJ 1 = Slovar slovenskega knjižnega jezika 1: A-H, Ljubljana, 1970.

Stang 1957 = Christian S. Stang, Slavonic Accentuation, Oslo, 1957. 
Steenwijk 1992 = Han Steenwijk, The Slovenian dialect of Resia: San Giorgio, Amsterdam, 1992.

Striedter-Temps 1963 = Hildegard Striedter-Temps, Deutsche Lehnwörter im Slovenischen, Wiesbaden, 1963.

Snoj 2003 = Marko Snoj, Slovenski etimološki slovar, Ljubljana, ${ }^{2} 2003$ ( $\left.{ }^{1} 1997\right)$.

Šekli 2003 = Matej Šekli, Odrazi praslovanskih oblikotvornih naglasnih tipov samostalnikov moške $o$-jevske sklanjatve v (knjižni) slovenščini, Jezikoslovni zapiski 9 (2003), št. 2, 29-50.

Šekli 2005 = Matej Šekli, Odraz medjezikovnih stikov v poimenovanjih za vaške poklice in dejavnosti v nadiškem narečju, v: Seminar slovenskega jezika, literature in kulture: zbornik predavanj 41, Ljubljana, 2005, 176-181.

Šekli 2008 = Matej Šekli, Naglasni sestav govora vasi Jevšček pri Livku nadiškega narečja slovenščine v luči relativne kronologije slovenskih naglasnih pojavov, v: Škrabčeva misel VI: zbornik s simpozija 2007, ur. Jože Toporišič, Nova Gorica, 2008, 19-36.

Šekli 2009 = Matej Šekli, Sklanjatev samostalnikov (moške in srednje) $o$-jevske sklanjatve v jeziku slovenskih srednjeveških rokopisnih spomenikov, v: Slovenski mikrokozmosi - medetnični in medkulturni odnosi = Zbornik Slavističnega društva Slovenije 20, ur. Irena Novak Popov, Ljubljana, 2009, 107-119.

Škrabec 1-4 = Stanislav Škrabec, Jezikoslovna dela 1-4: ponatis platnic časopisa Cvetje z vertov sv. Frančiška 1880-1915, ur. Jože Toporišič, Nova Gorica, 1994-1998.

Škrabec 1895-1896 = Stanislav Škrabec, Valjavčev »Prinos k naglasu u (novo)slovenskem jeziku« in prihodnja slovenska slovnica, Cvetje z vertov sv. Frančiška (Gorica) 14 (1895), št. 7-10, 12; 15 (1896), št. 1. Ponatis: Škrabec 2: 224-226, 228-230, 232-234, 236-238, 244-246, 248-250. [Navedeno po Škrabec 2.]

Toporišič 1992 = Jože Toporišič, Enciklopedija slovenskega jezika, Ljubljana, 1992. Toporišič $2000=$ Jože Toporišič, Slovenska slovnica, Maribor, ${ }^{4} 2000$ ( $\left.{ }^{1} 1976\right)$.

Valjavec 1878 = Matija Valjavec, Prinos k naglasu u novoj slovenštini: naglas u substantiva mužkoga roda, Rad Jugoslavenske akademije znanosti i umjetnosti (Zagreb) 45-48, Zagreb, 1878. 


\title{
Declension and accentuation of masculine $o$-stem nouns in the local dialect of Jevšček near Livek in the Natisone/Nadiža dialect of Slovenian
}

\author{
Summary
}

The historical linguistic interpretation of the declension and accentuation of masculine o-stem nouns in the local dialect of Jevšček near Livek in the Natisone/Nadiža dialect of Slovenian offers an important insight into the (comparative) historical morphology and accentology of Slovenian through at least two conclusive facts.

In the Natisone/Nadiža dialect, the reflexes of Proto-Slavic accent paradigm c nouns display the reflexes of Proto-Slavic masculine $i$-declension endings in the majority of plural forms (Npl glasjệ 'sounds' < *-bie, Gpl glasi < *-bìb, Apl glasî

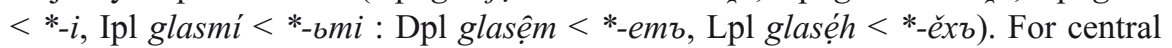
Slovenian dialects and standard Slovenian, this kind of accentual-declensional paradigm is characteristic only for the reflex of the Proto-Slavic masculine $i$-declension plurale tantum noun ljudjệ 'people' (i.e., ljudjệ, ljudī, ljudẹm, ljudî, ljudẹh, ljudmí) and, with the exception of the genitive and accusative plural, for some other nouns (standard Slovenian lasjệ 'hair', možjệ 'men', zobjệ 'teeth'; with variants also tatộvi/tatjệ ‘thieves', vozộvi/vozjệ 'wagons', volkộvi/volcjệ 'wolves', i.e., lasjệ, lás, lasệm, lasệ, lasẹ́h, lasmi), as well as some relict forms such as Apl dolgệ 'debts' and Lpl bregẹ́h 'slopes, banks'. The Natisone/Nadiža dialect material would then suggest that within the masculine $o$-stem declension with a mobile accent paradigm the accentual-declensional paradigm of the type lâs lasû 'hair', Npl lasjệ in Slovenian was more widespread in the past than it is in the present and that it was only later replaced by the accentual-declensional paradigm of Proto-Slavic (masculine) $u$-declension nouns of the type $\sin \operatorname{sinû}$ 'son', Npl sinộvi.

In the Natisone/Nadiža dialect (as well as in the Torre/Ter dialect) the reflexes of Proto-Slavic accent paradigm b nouns with a short vowel in final/sole stem syllable display the remnants of a stem accent in the locative (and instrumental) singular, and similarly in the locative and instrumental plural (könj konjä 'horse' . . . Lsg kọ́nju, Isg kọnjem, Lpl kọ́njih, Ipl kọ́nji). The reflex of the Proto-Slavic short neo-acute (with an early Post-Proto-Slavic lengthening) in the final/sole stem syllable in the locative and instrumental singular most probably arose by analogy with the original Proto-Slavic short neoacute in the final/sole stem syllable in the locative and instrumental plural. Whilst the plural forms display an original CommonSlovenian, the singular forms reflect an original Common-Slovenian short vowel. Consequently, it is possible to reconstruct the original end-stress paradigm with stress on the stem vowel in the locative and instrumental singular and plural at least for some Slovenian dialects (Slovenian: singular *kòn, *końà, *końù, *końà, *końi, *końèm, plural *końi, *kóń, *końèm, *koneè, *kònix, *kòni $)$, if not for all Slovenian linguistic territory. 